\title{
ポリクラール繊維紙の製造に関する研究
}

\author{
福岡県福島工業試験場 猿渡高治 \\ 工業技術院四国工業技術試験所 西山昌史，大山茂雄，松尾隆吉 \\ (物) 興 人 毛利邦夫
}

ポリクラール繊維は塩化ビニルの乳化重合によって得られるマエルジョンをポリビニルアルコールをマ トリックスとして湿式法により紡系されたものである。この繊維には熱水に易溶のものと難溶のものがあ る。前者を繊維間接着剤とし, 後者を主体繊維として, 従来から使用されている PVA バインダーやパル プと混合抄紙を行ない，それらの成紙について強度特性，抄紙性について次のような結果を得た。

1）易溶性ポリクラール繊維は繊維接着剂としての充分な機能を有し，ポリクラール繊維だけによる紙が 得られた。

2）難溶性繊維に対する接着剂としては紙力の点で易容性繊維より PVA バインダーの方が勝った。

3）易溶性繊維をパルプと混抄した結果，それは紙力増強剤としての挙動を示したが，その効果は PVA バインダーに劣った。

4）ポリクラール繊維紙は繊維組成中の PVC による難燃性を示した。

\section{Studies on the Papermaking by Polychlal Fiber}

Fukuoka Prefecture Fukushima Industrial Research Institute; Takaharu Saruwatari

Government Industrial Research Institute, Shikoku;

Masafumi Nishiyama, Shigeo Ōyama, Ryükichi Matsuo

Kojin Co., Ltd. Kunio Mōri

Polychlal fiber are produced by the wet spinning method of polymer-blend solution which is derived from polyvinyl alcohol and vinylchloride emulsion.

In hot water, these behave to melt easily and not do. The former was mixed as an adhesive and the later was used as a subject of the paper. On the other hand these was mixed with the PVA adhesive fiber or wood pulp being utilized as the adhesive or the subject of the paper from usual.

The obtained paper were investigated for these physical properties principally, and following results were given.

1) The former displayed the function enough to adhere fibers, and that was possible to make the paper of polychlal fiber only.

2) On the paper strength, polychlal fiber was inferior to the PVA adhesive fiber, when it behaved as a fiber-fiber binder.

3) The former behaved to strengthen the paper to mix and make the paper with the wood pulp.

4) The paper made with the polychlal fiber alone had the flame proofing property.

\section{1. 緒言}

従来合成繊維の製造には溶融, 乾式, 湿式の 3 種類 の紡糸方法があり，大部分の繊維は溶融，乾式の 2 種 類の紡糸方法で製造されている。しかし原料がビニロ ンの如く水溶性のものは湿式法によるが，エマジョン を原料とするものは不可能であった。ところが最近ポ リビニルアルコール (以下 PVA と略す) の存在下に
塩化ビニル（以下 VC と略す）を乳化重合して得ら れるエマルジョンポリマーから, 湿式紡系法で新しい 繊維を造ることが可能となり，これが工業化されたも のにポリクラール繊維（商品名コーデラン）がある。 この繊維は VC の乳化重合によって得られるェマ ルジョンポリマーよりの湿式紡糸が不可能であったの を，PVA をマトリックスとして紡糸した絨維であっ て, 紡糸原液はまず PVA の存在下に V C の乳化重 
合によるエマルジョンを作って物く。このエマルジョ ン中には PVA にV V がグラフト共重合したものが 含をれて和り，これに更にPVA をマトリックスとし て添加したもので，原液はグラフト共重合物の存在に より相分離を起さない安定なェマルジョンである。(1)

このよらな紡系原液より，湿式紡糸法で造られる繊 維の製造工程はビニロンと殆んど同じで，耐熱水性を 与えるためには最終工程でホルマル化が行なわれる。 このホルマル化が行なわれる以前の繊維はビニロンと 同じで，易溶性と難溶性のものが得られ，我々のビ二 ロン紙の研究からこれの合成繊維紙への利用は可能と 考えられる。そこでこの繊維紙の製造に関する研究を 行なったので報告する。

\section{2. 実験亡考察}

\section{2-1 供 試 試 料}

この実験に用いた各種ポリクラール緎維，PVA 瀻 維状接着剤，パルプについて次に示す。

(1) ポリクラール繊維

イ. 繊維 A; m.p. $=105^{\circ} \mathrm{C}$ 以上. $\mathrm{PVC} / \mathrm{PVA}=50 / 50$, $2^{d} \times 5 \mathrm{~mm}$.

口. 繊維B ; m.p. $=99^{\circ} \mathrm{C}, \mathrm{PVC} / \mathrm{PVA}=50 / 50$, $2^{d} \times 5 \mathrm{~mm}$.

八. 䋊維 C; m.p. $=83^{\circ} \mathrm{C}, \mathrm{PVC} / \mathrm{PVA}=50 / 50$, $2^{d} \times 5 \mathrm{~mm}$.

二. 繊維 D ; m.p. $=73 \sim 75^{\circ} \mathrm{C}, \mathrm{PVC} / \mathrm{PVA}=50 / 50$, $2^{d} \times 5 \mathrm{~mm}$.

(2) PVA 緎維状接着剤, VPB 105-2×3.

(3) パルプ, NBKP, C.S.F. $=430 \mathrm{cc}$.

\section{2-2. ポリクラール繊維の性質}

この繊維は上述したように, PVA の存在下に V C を PVA にグラフト共重合させて，得られた PVC ェ マルジョンにさらにPVAを添加して紡系原液を作り, その原液から湿式紡糸として得られたものであるから， 当然 PVA との混合比によって繊維の性質が変化する。

Table 1 Properties of polychlal fiber for the PVA/PVC ratio

\begin{tabular}{|c|c|c|c|c|}
\hline $\begin{array}{l}\text { PVC } \\
/ \text { PVA }\end{array}$ & $\begin{array}{c}\text { elongated } \\
\text { ratio }\end{array}$ & \begin{tabular}{|c|} 
tensile \\
strength \\
$(\mathrm{g} / \mathrm{d})$ \\
\end{tabular} & $\begin{array}{l}\text { elong } \\
\text { ation } \\
(\%) \\
\end{array}$ & $\begin{array}{l}\text { state after the } \\
\text { extraction of } \\
\text { PVA }\end{array}$ \\
\hline $0 / 100$ & 5.0 & 8.40 & 11.8 & melt \\
\hline $20 / 80$ & 5.0 & 5.67 & 20.8 & diffusion \\
\hline $40 / 60$ & 5.0 & 3.96 & 24.6 & $\begin{array}{l}\text { hold the fiber } \\
\text { form }\end{array}$ \\
\hline $50 / 50$ & 5.0 & 2.75 & 35.2 & " \\
\hline $60 / 40$ & 5.0 & 1.68 & 34.8 & 11 \\
\hline
\end{tabular}

表 1 の紡糸原液は PVC のエマルジョン濃度 $31.2 \%$, 粒子径 $300 \AA ， P V A$ の平均重合度は 1700 で完全ケン 化物である。紡系浴は $45^{\circ} \mathrm{C}$ の飽和ボウ硝液で延伸は 湿熱, 乾熱, ローラ延伸を行ない，湿熱延伸は $85^{\circ} \mathrm{C}$ の飽和ボウ硝液中で，乾熱延伸は $160 \sim 180^{\circ} \mathrm{C}$ の空気 浴で，ローラ延伸は室温で，後の熱処理は $225^{\circ} \mathrm{C}$ の 空気浴で 15 秒䦓処理したものである。(2)

表1にみられるよらに, 繊維組成中の PVA が減少 し PVC が増加するにしたがって単纎維強度は低下し, 伸度は大きくなっている。そしてこの繊維中の PVA の熱水抽出後の繊維形態は, PVC $40 \%$ 以上のものが 繊維形態を保っている。このことは，PVC 40\% 以上 のものは PVC のエマルジョン粒子が PVA をマトリ ックスとして融着連続化して繊維化していることで, 実際は PVC と PVA の比が 50/50 のものが商品化 されている。表 2 に参考のため市販品の一般的性質を 示す。

Table 2 General properties of polychlalfiber ("Cordelan" F type) (3)

\begin{tabular}{|c|c|c|}
\hline \multirow{2}{*}{$\begin{array}{l}\text { tensile } \\
\text { strength } \\
(\mathrm{g} / \mathrm{d})\end{array}$} & dry & $2.8 \sim 3.3$ \\
\hline & wet & $2.0 \sim 2.3$ \\
\hline \multirow{2}{*}{$\underset{(\%)}{\text { elongation }}$} & dry & $20 \sim 24$ \\
\hline & wet & $20 \sim 24$ \\
\hline $\begin{array}{l}\text { apparent } \\
\text { Young's } \\
\text { modulus } \\
\left(\mathrm{kg} / \mathrm{mm}^{2}\right)\end{array}$ & & $300 \sim 400$ \\
\hline $\begin{array}{l}\text { modulus of } \\
\text { elasticity } \\
(\%)\end{array}$ & $\begin{array}{c}\text { elongation } \\
\text { of } 3 \%\end{array}$ & $80 \sim 90$ \\
\hline \multirow{2}{*}{$\begin{array}{l}\text { heat-proofing } \\
\left({ }^{\circ} \mathrm{C}\right)\end{array}$} & $\begin{array}{c}\text { softening } \\
\text { temp. }\end{array}$ & $180 \sim 200$ \\
\hline & $\begin{array}{l}\text { begining temp. } \\
\text { of contraction }\end{array}$ & $170 \sim 180$ \\
\hline flame-proofing & & $\begin{array}{l}\text { non-self combu- } \\
\text { stion, immediately } \\
\text { die out to detach } \\
\text { the flame }\end{array}$ \\
\hline \multirow{2}{*}{\begin{tabular}{|c|} 
stability in \\
acids or alkalis \\
influence of \\
chemical \\
reagents \\
\end{tabular}} & & good \\
\hline & & $\begin{array}{l}\text { generally hold } \\
\text { a good resistance }\end{array}$ \\
\hline $\begin{array}{c}\text { influence of } \\
\text { solvents }\end{array}$ & & $\begin{array}{c}\text { hold a goodness } \\
\text { for the } \\
\text { drycleaning }\end{array}$ \\
\hline $\begin{array}{l}\text { influence of } \\
\text { insects or } \\
\text { molds }\end{array}$ & & $\begin{array}{l}\text { hold the perfect } \\
\text { resistance }\end{array}$ \\
\hline
\end{tabular}

表にみられるように，引張強度は湿潤時兮乾燥時よ り低いが，伸度は乾湿とも変化がなく，耐焰性として 自然性がないことが大さな特徴である。

次にこの瀻維の熱水浸漬下の挙動を顕微鏡観察した 結果を写真に示す。 


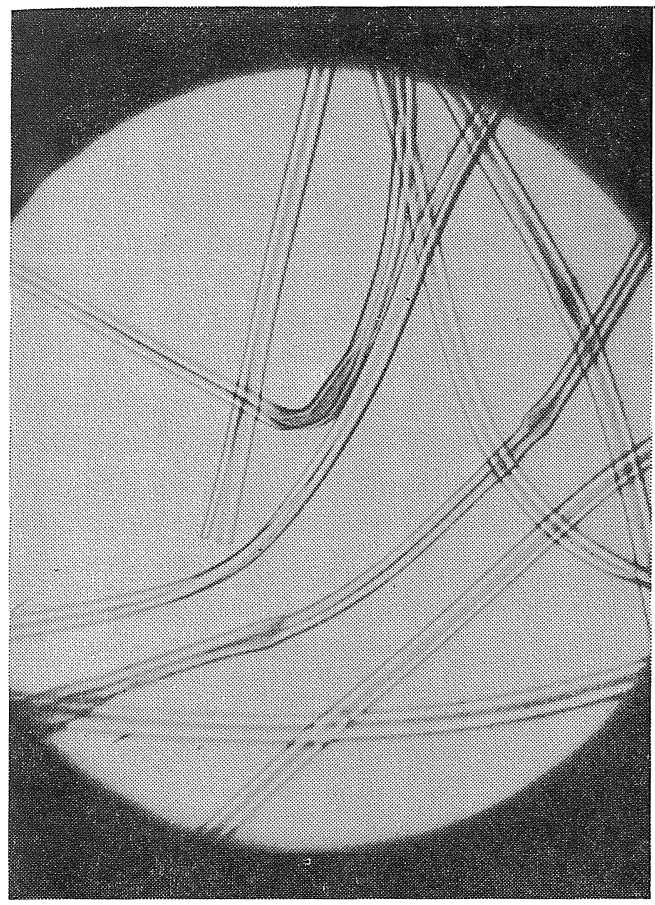

Photo 1 Original fiber

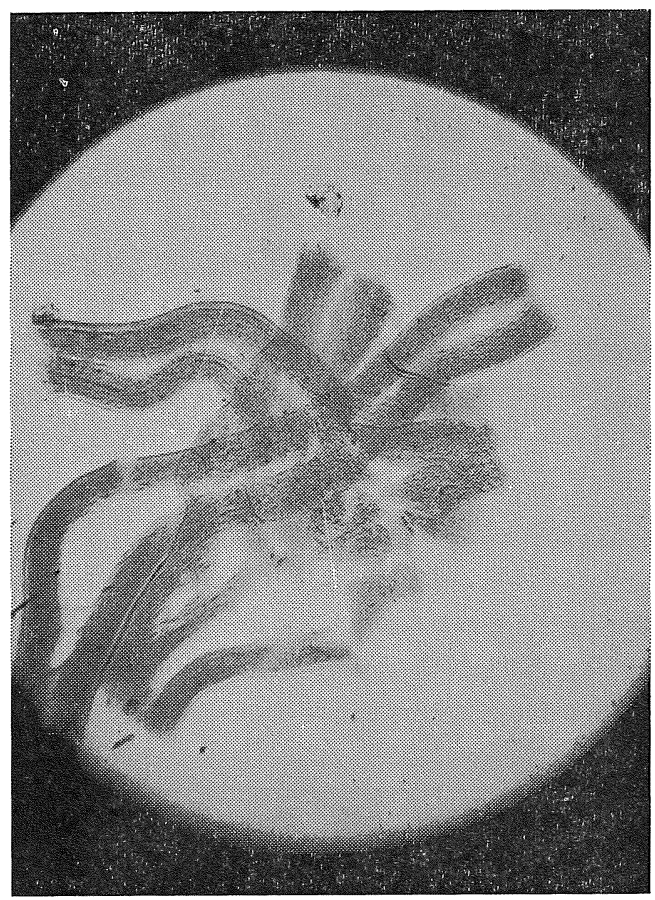

Photo $375^{\circ} \mathrm{C}$

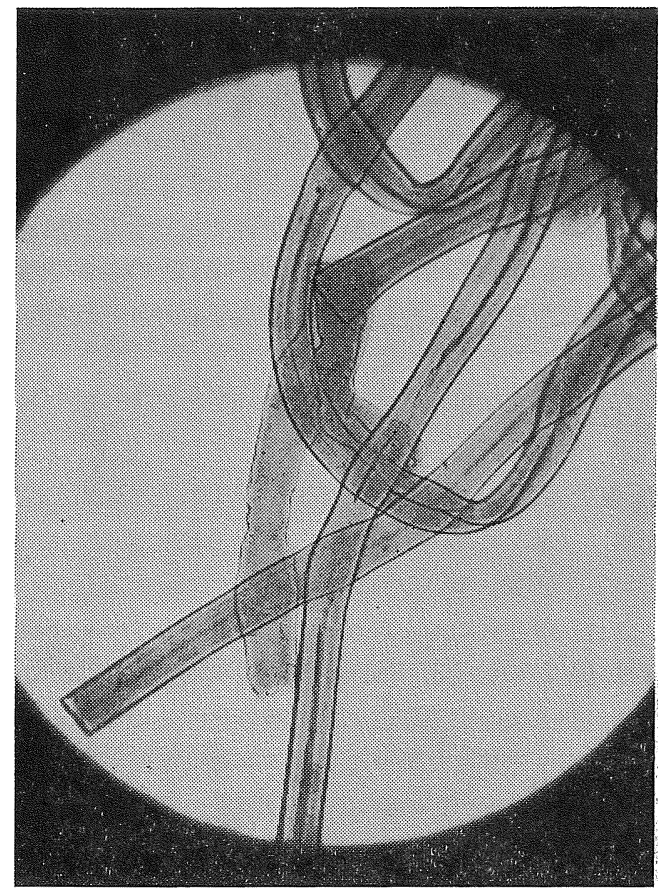

Photo $270^{\circ} \mathrm{C}$

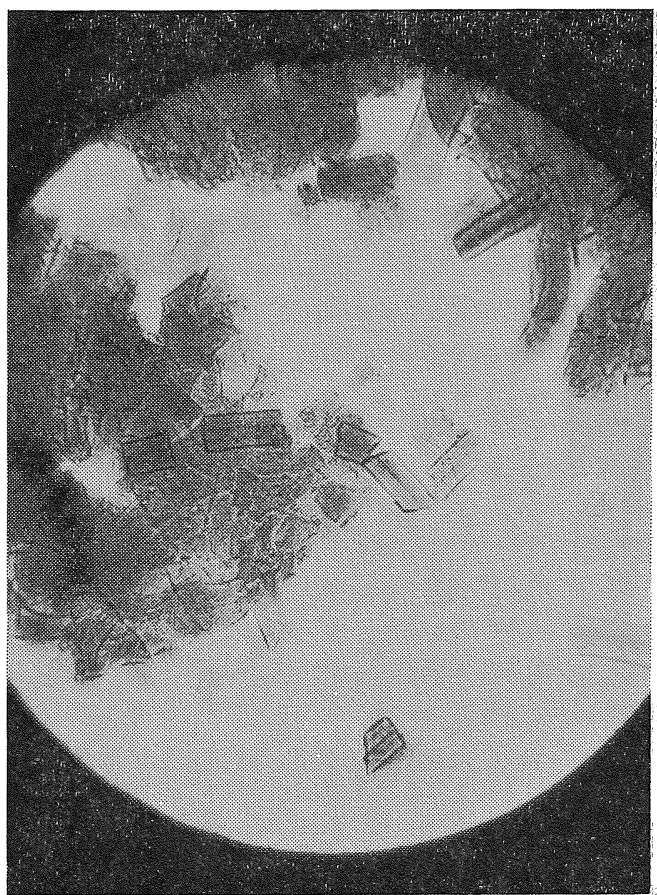

Photo $480^{\circ} \mathrm{C}$

Photographs, photomicrograph of the polychlal-fiber in hot water, $70,75,80^{\circ} \mathrm{C}$. 
前にも述べたように，この緎維の製造工程がビニロ ンのそれと汪とんぞ同じであるが，表1より PVCの エマルジョン粒子が PVA 中で融着連続化して繊維化 しているものと，していないものとがあるはずで，こ れがこの纎維の易溶性と難溶性との大きな相違になる はずである。そこでまず易溶性繊維に相当する $1.5 \mathrm{~d} \times$ $.4 \mathrm{~mm}$ のものを選んで $70^{\circ} \mathrm{C}, 75^{\circ} \mathrm{C}, 80^{\circ} \mathrm{C}$ の各々の熱 水浸漬になるよう中温加熱炉中で加熱して，それを顕 微鏡で観察したものである。

写真 1 は原繊維で, 写真 2 は $70^{\circ} \mathrm{C}$ の浸漬状態であ るが，縬維は膨潤が著しく写真 3 の $75^{\circ} \mathrm{C}$ になると PVA が溶解し始好崩壊しかかっている。写真 4 では 完全に PVA が溶解し，PVC の粒子は融着連続化し て持らず崩壊しているのがわかる。

これらの写真にもみられるように, ポリクラール瀻 維は PVC の粒子が PVA の溶液中に均一飞分散し, これが紡系後の熱処理によって繊維化するのであるが, 熱処理が不充分なためマトリックスの PVA が溶解す るとともに，PVC の融着不充分のものが崩壤して熱 水中に不溶解分として残る。これはポリクラール繊維 紙製造の場合に考虑すべきものと思われる。この他難 溶性に相当する瀻維を $95^{\circ} \mathrm{C}$ の熱水に浸漬して観察し たが繊維は膨潤するだけで他に变化はみられなかった。

\section{2-3 難溶性及び易溶性ポリクラール繊維の混抄}

顕微鏡観察からもわかるように易溶性のものは $75^{\circ} \mathrm{C}$ 附近で熱水に溶融するところから，ビニロン紙 製造の手法を用いて難溶性のものを主体瀻維とし，易 溶性のものを瀻維間接着片として混抄し, ポリクラー ル䋊維だけによる紙を試作し，これの物理的特性と抄 紙性について検討した。抄紙はいずれも粘剤としてポ リエチレンオキサイド（PEO）を用い，TAPPI スタ ンダードシートマシンによって行ない，95 $100^{\circ} \mathrm{C}$ に て譤燥した。

\section{2-3-1 瀻維 A と瀻維 D の混抄}

前者は製造工程中でも耐熱性向上の為に行なわれる ホルマル化の後に得られるもので, 難溶性繊維の中で も最も耐熱度の高いものである。これに易溶性の後者 を種々の配合比で混抄し，得た成紙について諸強度の 検討を行なった。

繊維 D は A 飞対して纎維間接着剂として働き, 混 合量の増加に伴なって諸強度は増大している。同じ難 溶性繊維でも特に注意すべきは熱水溶融温度と紙葉乾 燥温度である。つまり溶融温度が乾燥温度より高いか， 低いかとより諸強度への影響も大さい。主体繊維とし て用いた繊維Aの場合には，顕徵鏡観察からもわかる ように膨潤するだけで乾燥による影響は受けていない

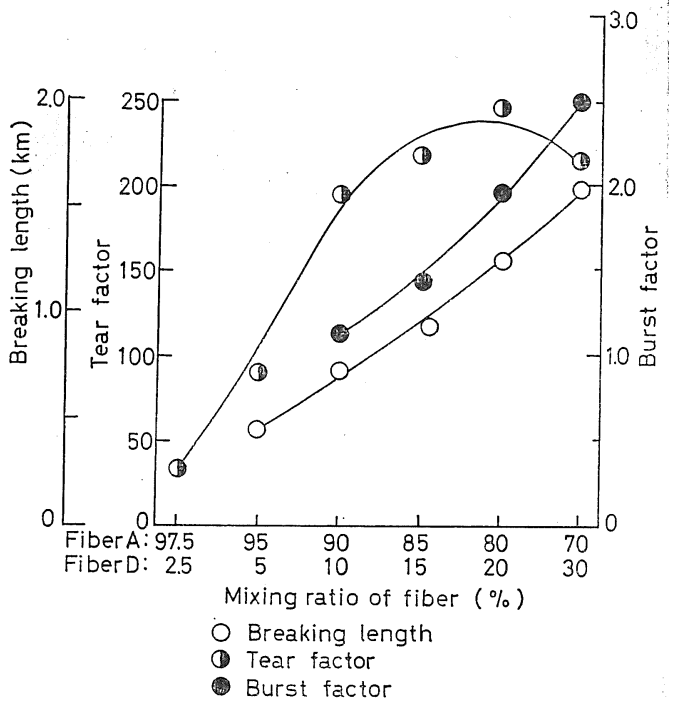

Fig. 1 Strength of the paper made of Fiber $\mathrm{A}$ and Fiber D.

ものと考兄られる。繊維 D だけが乾燥時に溶融して 繊維間の接着の寄与しているものである。この点にお いて後述する繊維 $\mathrm{B}, \mathrm{C}$ と繊維 D の混抄紙と比較し た場合の強度の差異に興味が持たれる。

\section{2-3-2 繊維 B 々繊維 D の混抄}

繊維 B はホルマル化工程の前に得られるもので, その溶融温度は繊維 $\mathrm{A}$ 飞比べわずかに低くなってい る。そこでこれを繊維 D と混合，抄紙して繊維 A一 D の混抄紙之強度についての比較をした。

その結果, 引裂強度を除を引張, 破裂の各強度とも かなりの増加を示した。このことは2-3-1，でもふれ たが繊維 $\mathrm{A}$ と B との溶融湿度の差によるものと考光 られ，乾燥温度よりやや低いところに溶融点をもつ繊 維 B はとの一部が溶融して自己接着性を有している とみることができ，結果的には接着剤としての繊維 D の混合率を高めたのと同様になる。又, 引裂強度 そついてみると，繊維 A-D の混抄紙では配合比 80 /20 そピークを持ち最高值も 245 あったものが, 㵶維 B一D の混抄紙ではピークが配合比 $85 / 5$ 亿移行し, 最高値も 216 と約 $12 \%$ 低くなっていることからも推 察される。

\section{2-3-3 繊維 C と繊維 D の混抄}

繊維 C は B K比べ更に溶融温度の低いもので, そ の成紙に括いては当然乾燥時に和ける溶融がかなり進 行しているものと考光られる。それ故瀻維 A, B の 混抄紙に比べ, 繊維 C の混抄紙は破裂, 引張強度に 特いて著るしい伸びを示しているとともに接着瀻維で 


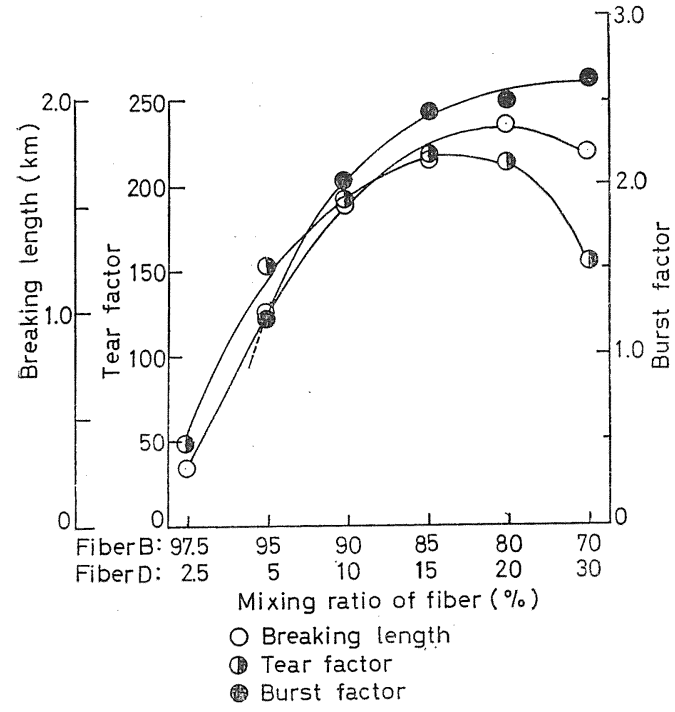

Fig. 2 Strength of the paper made of Fiber B and Fiber D.

ある紻維 D の混合率が増加するにつれ強度は低下の 傾向を示している。引裂強度についても同様のことが い光る。

以上, 繊維 $\mathrm{A}, \mathrm{B}, \mathrm{C}$ の 3 種類の難溶性繊維之繊 維間接着剂としての繊維 D の混抄とついて述べたが, 溶融温度の差による強度上の問題はあるにしろ実験的 にはポリクラールだけによる紙の製造が可能であるこ とがかかった。しかし従来方ら製紙用として使用され ているビニロン緘維 100\% の紙と比較した場合, 強度

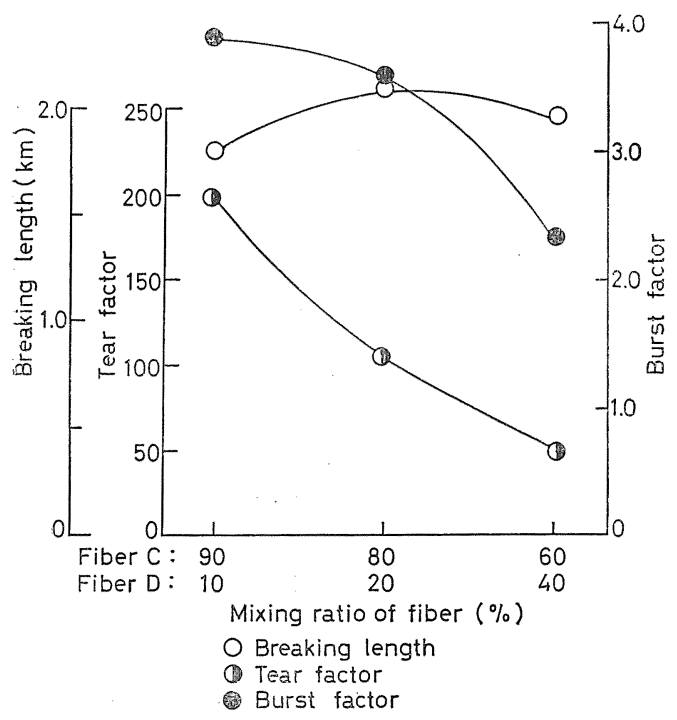

Fig. 3 Strength of the paper made of Fiber $\mathrm{C}$ and Fiber D.
面では劣るようであるが成紙自体としての諸強度は満 足すべきもと考兄られる。

\section{2-4 難溶性䊼維（繊維 $\mathbb{B}$ ) と PVA 䊼維状接着剂 の混抄}

前述のようにポリクラール繊維 100\% の紙の製造が 可能なことがわかったが，従来から化学合成繊維紙の 接着剂には一般に PVA 瀻維状接着剤が用いられてい る。このものの縅維組成が PVA 100\%であるのに比 ベ，易溶性ポリクラール纎維では組成中の PVA が50 \%となっていることは当然繊維間の接着力に和いて差 異が生じるものと考光られる。そこで繊維Bを主体瀻 維とし, これに PVA 繊維状接着剂を混抄して強度面 の比較検討を行なった。

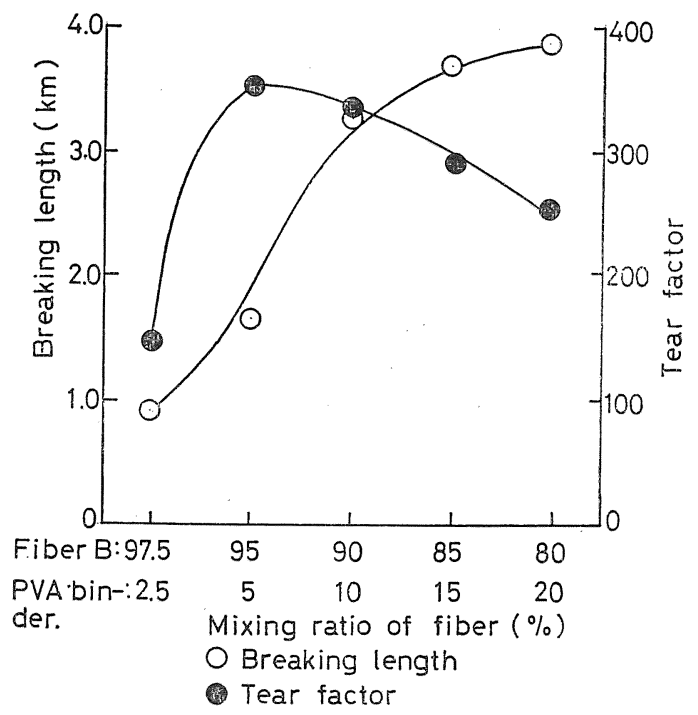

Fig. 4 Strength of the paper made of Fiber B and PVA binder

その結果 PVA 接着剂の混抄紙の方が引張, 引裂強 度ともに優った。これは主体瀻維自体にも多少の自己 接着性があるが，PVA 接着郕と繊維 D 亿ついて比較 すると，溶融して接着作用にあずかる組成分としての PVA の含有量が前者に比べ後者は半分であるところ に起因しているものと思われる。このことは図の引裂 強度を例にとると，PVA 接着剂では $5 \%$ の混抄で最 高となるのに対して，繊維 D では最高値が 15\% 混抄 のところに来ていることからも推察できる。

\section{2-5 パルプと易溶性ポリクラール絨維の混抄}

難溶性及び易溶性ポリクラール繊維の混抄において 後者は接着剤的効果のあることが判明したので，これ を紙力増强剤としてパルプに混合抄紙しその成紙につ いて検討を行なった。ただしポリクラール繊維は繊維 $\mathrm{D}$ 相当のもので $1.5 \mathrm{~d} \times 4 \mathrm{~mm}$ のものを用いた。 


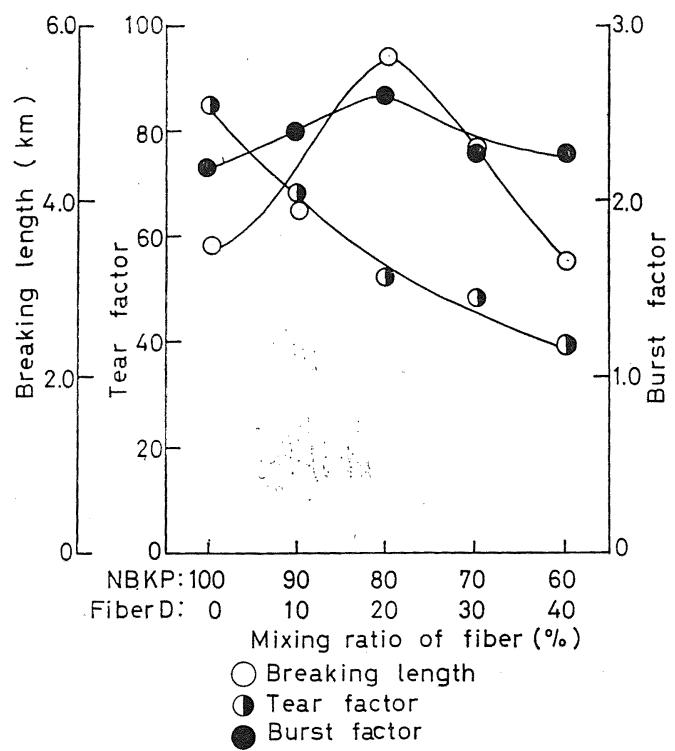

Fig. 5 Strength of the paper made of NBKP and Fiber D.

この成紙に和けるポリクラール繊維の混合量は乾燥 時の紙葉のドライヤーへの融着のため $40 \%$ が限度で あった。成紙強度は引張，破裂強度については混合量 の増加とともに増し，20\%で最高となった。一方引裂 強度はパルプだけの紙より低下している。これは PVA 繊維状接着剤の混合の場合と同じ傾向を示すも のであり，易溶性ポリクラール繊維組成中の PVA \& これと同様の挙動をしていると考えられる。

\section{2-6 ポリクラール絾維紙の難燃性について}

最近，火災事故による損害が増大している折から建 築，インテリア素材の難燃化に強い関心がよせられ， 消防法等の改正ともあいまって一部では難燃材の使用 が義務づけられて来ている。

紙も從来からの障子紙やふすま紙に加兄最近では生 活様式変遷に伴い壁紙やその他室内装飾的な方面での 需要が高まりつつあり, 従来の天燃繊維や化学繊維等 可然性のものは用途によっては何らかの処理, あるい は成紙素材そのものの転換によって難然化することが 急務となっている。

ポリクラール繊維は始めにも述べたように PVC と PVA のポリマーブレンドによる合成繊維であるため， このうらの PVC に起因する自己消火性を有している。 そこでポリクラール繊維 100\%の紙及びこれにレーヨ ンを混抄した場合の紙について，タッピ・スタンダー ドの試験方法に基づき金枠に試片を垂直に固定し，こ れにガスバーナーの炎を一定時間あてた後，炭化長を
Table 3 Flame-proofing test of the polychlaI fiber paper.

\begin{tabular}{|c|c|c|c|c|}
\hline \multicolumn{2}{|c|}{ ratio of mixtures } & $\begin{array}{c}\text { areal } \\
\text { weight } \\
\left(\mathrm{g} / \mathrm{m}^{2}\right)\end{array}$ & $\begin{array}{c}\text { carbonized } \\
\text { length } \\
\text { (mm) }\end{array}$ \\
\hline Fiber A & Rayon & Fiber D & 67 \\
\hline 80 & 0 & 20 & 66.6 & 87 \\
75 & 5 & 20 & 67.0 & 104 \\
70 & 10 & 20 & 69.6 & 122 \\
65 & 15 & 20 & 67.0 & 140 \\
60 & 20 & 20 & 66.5 & 153 \\
55 & 25 & 20 & 67.5 & self- \\
50 & 30 & 20 & 67.0 & combustion \\
40 & 40 & 20 & 66.9 & "' \\
\hline
\end{tabular}

測定しその防炎性について検討した。

この結果，ポリクラール繊維 100\%の紙については かなりの防炎性が認められた。一方レーヨンを混抄し ていくと炭化長も長くなり混抄率が $25 \%$ を越えると 防炎性は全く失われ，レーヨンは助然剤のよらな挙動 を示した。

従来から無機薬品による難燃処理は広く行われてい るが変色，増湿等解決さるべさ諸問題が残されて和り， 繊維そのものに難然又は不然性を具備しているものと してはガラス緎維，石綿等特殊なものに限られ紙の素 材として常用されるものではなかった。この点から もポリクラール繊維は今後に期待の持たれる䋐維であ る。

\section{3. 総括}

PVA と PVC のポリマーブレンドにより得られる ポリクラール繊維を利用した紙の製造と特性について 検討した結果，次のような知見を得た。

（1）ポリクラール繊維はその製造工程中，熱処理工 程あるいはホルマル化工程の如何によって，熱水に易 溶のものと難溶のものとがあり，その溶融温度も各種 のものが得られ顕微鏡観察の結果, 溶融点の低いもの は水温の上昇ともに膨潤，崩壊し，高いものは膨潤す るだけで紼維形態を保った。

（2）熱水溶融温度の異なる繊維を混合抄紙して得た 紙は，易溶性繊維が接着剂として主体繊維として使用 した難溶性繊維の繊維間接着に大きく寄与し，ポリク ラール繊維だけによる紙を造り得たが紙力は従来の合 成繊維に劣った。

（3）パルプに易溶性繊維を混抄したところ，紙力増 強剂としての挙動を示したが，その効果はPVA 繊維 状接着剂より劣った。 
（4）主体繊維として使用した難溶性ポリクラール繊 維に, PVA 繊維状接着剂を混抄したところ易溶性繊 維より紙力の点では優ったが, 可能配合比は狭い幅で あった。

（5）ポリクラール繊維の組成中，PVC による難燃 性に着目乙て成紙の防炎試験を行なった結果，ポリク ラール繊維 100\%の紙についてはかなりの効果が認め られた。これにレーヨンを順次配合比を増していった 結果 10\%配合までは効果が認められたが，25\%配合 を越えるとレーヨン繊維は助然剤として働さ, 成紙の 自己消火性は全く失われた。

ポリクラール繊維は工業化されて日も浅く, 製紙用
原料としては満足すべきものではないが，今後の研究 により改善されるならば興味のあるものとなろら。終

りに各種試料を提供された(侏興人八代支社に厚く謝意 を表する。

文献

1）朝倉宏；繊維と工業，Vol. 21，26（1965）

2) 第 12 回高分子大会; 東洋化学研究所発表要旨

3) (㧣興人，パンフレット“コーデラン”

4）是松; 高分子加工，6，25（1969）

5）是松；化繊紙研究会誌，6，34（1967）

（原稿受付 昭 46.1 .8 )

\section{TAPPI 26th Engineering Conference}

時 期：1971年11月 14-18日

会 場：Regency Hyatt House, Atlanta, Ga., U.S.A. 技術的プログラム：機械技術関係, 液体の機構, 蒸気 と動力, 工業技術関係, 圧縮と乾燥, 電気技 術, 腐食と材料の選択，プロセス・システム と制御，保守技術，技術経済と計画管理

出席希望者は上記ホテル宛, TAPPI 関係と付記して 直接申込むこと。

紹介先: Mr. H. O. Teeple, TAPPI, 360 Lexington Avenue, New York, N. Y. 10017, U.S.A.

(松 井)

The 1st Paper Makers Conference (1972)

主 催: TAPPI

時 日：1972年 6 月 5-8日

会 場: Sheraton Biltmore Hotel, Atlanta, Georgia, U.S.A.

報文発表の主題: 化学薬品, 長綱抄紙機, すきあわせ 板紙原料調成, 繊維原料, 湿潤強度, 繊維間 給合関係で従来は TAPP の年間各種会議に 分割して，処理されていたもの。

報文の提出希望の場合の紹介先：

Technical Program Chairman, Mr. A. Pociluyko, Scott Paper Co., Scott Plaza, Pa. 19113, U.S.A.

出席希望の場合の紹介先:

Mr. H. O. Teeple, TAPPI, 360 Lexington

Avenue, New York, N.Y. 10017, U.S.A. 宿舎の予約は上記ホテル TAPPI 関係と言及乙て直 接申达むことになっている。

(松 井)

The 3rd TAPPI/CPPA Paper Physics Conference
時 期：1971 年 9 月 20-23日

会 場: Mont Gabriel Lodge, Montreal, Quebec, Canada

分科会：(1)紙匹形成と構造; (2)構成特性関係; (3)繊維 と結合特性；(4)一般繊維紙の特性関係；(5)繊; 維特性に関連する機械的特性；(6)紙のその他 の特性

照会先：Mr. D. H. Peterson, Tech. Section, CPPA, 2300 Sun Life Bldg., Montreal 110, Quefec. Canada または

Mr. M. J. Williams, TAPPI, 360 Lexington Avenue, New York 17, N. Y. 10017, U.S.A.

(松 井)

\section{技協誌 6 月号掲載研究報告訂正}

$\mathrm{SCP}$ 廃液の熱分解に関する研究 (第 2 報) 還元性方 几囲気での熱分解……長屋喜一，仲田俊之，橘登志夫， 前田一雄の 4 氏の研究報告に編集上の手落ちがありま したので，次のように訂正させて戴さます。

p. 29 Fig. 4 の図に p. 31 Fig. 7 の図を入れる

(Fig. の標題, 説明はそのまま)

p. 30 Fig. 5 の図に p. 31 Fig. 8 の図を入れる.

(Fig. の標題, 説明はそのまま)

p. 30 Fig. 6 の図に p. 29 Fig. 4 の図を入れる

(Fig. の標題, 説明はそのまま)

p. 31 Fig. 7 の図に p. 30 Fig. 5 の図を入れる

(Fig. の標題, 説明はそのまま)

p. 31 Fig. 8 の図に p. 30 Fig. 6 の図を入れる

(Fig. の標題，説明はそのまま)

(編集部) 